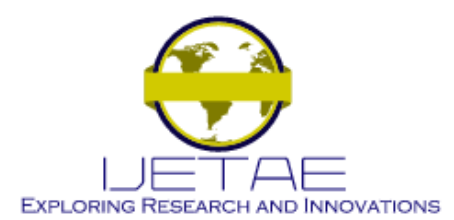

International Journal of Emerging Technology and Advanced Engineering

Website: www.ijetae.com (ISSN 2250-2459, ISO 9001:2008 Certified Journal, Volume 10, Issue 07, July 2020)

\title{
Evaluation of the Fertility of Alluvium From Nyong Valley (Cameroon): Prospection of Agricultural Areas.
}

\author{
Samba Assomo P. ${ }^{1}$, Kouayep Lawou S. ${ }^{2}$, Okomo Atouba L. C. ${ }^{3}$, Kamgang Kabeyene B.V. ${ }^{4}$ \\ 1,2,3,4 Higher Teacher Training College of Bertoua, University of Ngaoundéré, Po. Box. 652 Bertoua, Cameroon.
}

\begin{abstract}
The Akonolinga region is located in southcentral Cameroon in the Nyong river basin. In order to seek fertile areas, in a ferralitic environment, for their agricultural development, the alluvium of the Nyong valley was harvested. The samples used for chemical analysis and the determination of fertility parameters were taken through three dark soil wells for this purpose. The results obtained show a predominance of silica $\left(\mathrm{SiO}_{2}\right)$. The $\mathrm{pH}$ is acidic with a low cation exchange capacity (CEC), the contents of exchangeable cations are generally low. However, compared to ordinary ferralitic soils, derived alluvium has fertility advantages thanks to a fairly high $\mathrm{pH}$ $(\mathrm{pH} \approx 5)$, an abundance of organic matter and water permanence. These characteristics can be favorable for the development of market gardening or industrial aquatic agriculture.
\end{abstract}

Keywords-- Nyong valley, Akonolinga, alluvium, fertility

\section{INTRODUCTION}

The idea of characterizing fertility is often a reference to well-organized soils because of their location on the interfluves and their agrarian space (Dooremboss et Kassam, 1980; Medjo Akoo, 1982; Boyer, 1982; Landon, 1984; Posner 1988; Nyeck, 1989; Marx et al ,1996; Voundi Nkana, 1998; Dembele 2000; Meyim Dayombo, 2000; Yemefack, 2005). Alluvial environments do not seem to have the same advantages despite the limitation of space and water dynamics (Ndam,1997; Bineli,2009; Samba et al 2015). These low altitude areas, in addition to their muddy character, constitute a receptacle for waste of all kinds and are qualified as areas with vulnerable ecology (Ndam, 1997; Bineli,2009). From the point of view of fertility, alluvial environments could be interesting for more than one reason (Muniasmy et al., 2013).
The abundance of organic matter and water constituting undeniable advantages in the feeding of vegetation (Samba et al 2015). However, account must be taken of the type of crop, the nutritional requirements of the plants to be grown and the movements of the water (Guignard, 1994). It is in this perspective that a study is being carried out in the valley of Nyong river from Akonolinga with a view to assessing the fertility of the alluvium associated with this important river.

\section{ENVIRONMENTAL SETTING}

The present alluvial fertility study was carried out in the Nyong valley from Akonolinga. The basin of Nyong River with $27,800 \mathrm{Km}^{2}$ of area is situated in central Africa in southern forest ecosystem of Cameroon. It extends from $2^{\circ} 48^{\prime}$ to $4^{\circ} 32^{\prime} \mathrm{LatN}$ and from $9^{\circ} 54^{\prime}$ to $13^{\circ} 30^{\prime}$ Long Est (Fig. 1). It is limited in North by Sanaga basin, in east by a part of Congo basin, in west by Atlantic Ocean and by Ntem basin in south. The work site covers an area of 16,000 . The geographic coordinates of the opened-wells are as follows: P1: N03 '46'08' ' and E012 '14'41', P2: N03 '46'07' and E $012^{\circ} 14^{\prime} 32^{\prime \prime}$; P3: N $033^{\circ} 46$ '02' and E $012{ }^{\circ} 14{ }^{\prime} 3$. The Nyong River originates in the locality of Djouyaya south-east of Abong-Mbang precisely in the Guimberi mountains in East Cameroon. It flows along a winding route oriented ENE-WSW before throwing itself into the Atlantic Ocean after a course of $690 \mathrm{~km}$. Its bed is encased in a marshy valley under forest at $650 \mathrm{~m}$ from altitude (Ndam, 1997; Bineli, 2009; Samba et al., 2015). This valley widens considerably in Akonolinga and forms an important terrace of aquatic grasses developed on alluvial deposit. 


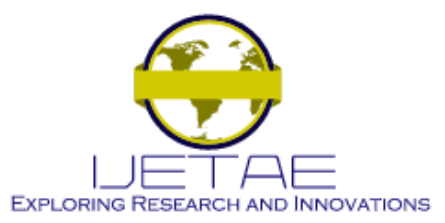

International Journal of Emerging Technology and Advanced Engineering

Website: www.ijetae.com (ISSN 2250-2459, ISO 9001:2008 Certified Journal, Volume 10, Issue 07, July 2020)
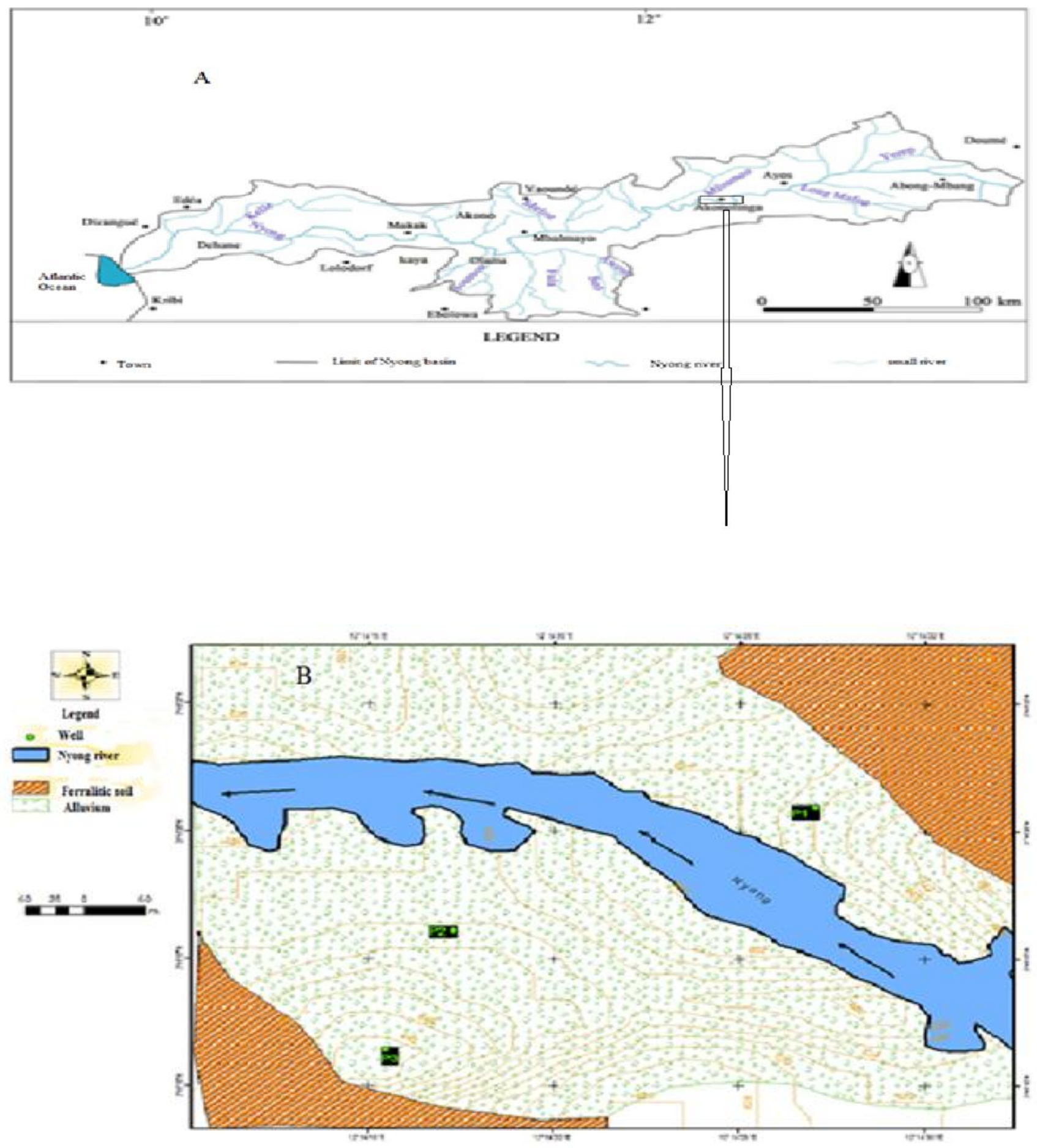

Fig. 1. Geographical location of the study area. A: Nyong basin; B: site of study

\section{MATERIALS AND MEthods}

In order to carry out this study, three wells were sunk (Tremblay and Robitaille, 1997) inside the alluvial terrace of Nyong. The wells are noted P1, P2 and P3 including $\mathrm{P} 2$ and $\mathrm{P} 3$ on the left bank and $\mathrm{P} 1$ on the right bank. The depth of each well is $1 \mathrm{~m}$.
Five levels of sample collection have been adopted, notably at $0 \mathrm{~cm}, 20 \mathrm{~cm}, 50 \mathrm{~cm}, 80 \mathrm{~cm}$ and $100 \mathrm{~cm}$. The wells were opened using manual work tools (picks, augers, shovels, machetes). 


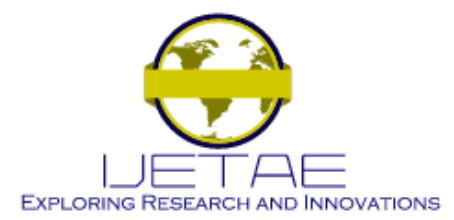

International Journal of Emerging Technology and Advanced Engineering Website: www.ijetae.com (ISSN 2250-2459, ISO 9001:2008 Certified Journal, Volume 10, Issue 07, July 2020)

The collected samples were packed in plastic sample bags and separated into two lots, one of which was for chemical analysis and the other for fertility assessment. The fertility parameters were determined at the analysis laboratory of the Agricultural Research and Development Institute (IRAD) of Cameroon while the determination of the overall chemistry of the samples was carried out at the geochemistry laboratory of the Mission for the Promotion of Local Materials (MIPROMALO) from Cameroon. The labeling of the sample takes into account the name of the city of origin of the sample and the number of the well on the one hand then of the sampling site and the depth of harvest on the other hand. The code A2NY80 means: sample from the town of Akonolinga (A) taken from the second well (2) of the Nyong valley (NY) at a depth of $80 \mathrm{~cm}$. The dimensions of the study site were measured using a triple decameter and its area of $16,000 \mathrm{~m} 2$ determined by calculation.
The plant species belonging to this area were harvested using the transet method (Kamgang Kabeyene, 1998) and the prepared herbaria were sent to the National Herbarium in order to carry out the floristic inventory.

\section{RESUlts}

\section{4-1 Geochemistry}

The results of the overall chemical analysis of the samples are shown in Table 1. From the analysis of these results, it appears that the silica $\left(\mathrm{SiO}_{2}\right)$ is highly concentrated to the detriment of all the other elements with a content varying between $43 \%$ and $74 \%$. Alumina $\left(\mathrm{Al}_{2} \mathrm{O}_{3}\right)$, iron $\left(\mathrm{Fe}_{2} \mathrm{O}_{3}\right)$ and titanium $\left(\mathrm{TiO}_{2}\right)$ are secondarily associated with silica in the respective proportions of $5 \%$ to $15 \% ; 0.7 \%$ to $6 \% ; 0.6 \%$ to $2 \%$. The sum of alkali and alkaline earth $\left(\mathrm{K}_{2} \mathrm{O}+\mathrm{CaO}+\mathrm{MgO}\right)$ is everywhere low and fluctuates around $0.4 \%$. The $\mathrm{SiO}_{2} / \mathrm{Al}_{2} \mathrm{O}_{3}$ ratio is very high in all the samples and varies between 4 and 7 , recalling a prevalence of silica compared to alumina. The other elements have extremely low contents.

Table 1

Chemical composition of samples in different wells (\% of oxides)

\begin{tabular}{|l|l|l|l|l|l|l|l|l|l|l|l|l|l|l|l|}
\hline Wells & Samples & $\mathrm{SiO}_{2}$ & $\mathrm{Al}_{2} \mathrm{O}_{3}$ & $\mathrm{TiO}_{2}$ & $\mathrm{Fe}_{2} \mathrm{O}_{3}$ & $\mathrm{~K}_{2} \mathrm{O}$ & $\mathrm{MgO}$ & $\mathrm{MnO}$ & $\mathrm{NiO}$ & $\mathrm{P}_{2} \mathrm{O}_{5}$ & $\mathrm{CaO}$ & $\mathrm{Cr}_{2} \mathrm{O}_{3}$ & $\mathrm{H}_{2} \mathrm{O}$ & $\mathrm{LOI}$ & $\mathrm{SUM}^{\prime}$ \\
\hline $\mathrm{P} 1$ & $\mathrm{~A} 1 \mathrm{NY50}$ & 43.03 & 5.74 & 0.65 & 0.78 & 0.20 & 0.11 & 0.10 & 0.10 & 0.30 & 0.13 & 0.12 & 35.00 & 13.74 & 100.00 \\
\hline & $\mathrm{A} 1 \mathrm{NY100}$ & 74.70 & 11.10 & 2.00 & 0.80 & 0.30 & 0.20 & $\mathrm{ND}$ & $\mathrm{ND}$ & 0.10 & 0.15 & 0.10 & 4.00 & 6.55 & 100.00 \\
\hline $\mathrm{P} 2$ & $\mathrm{~A} 2 \mathrm{NY50}$ & 59.96 & 11.00 & 1.5 & 1.10 & 0.30 & 0.10 & $\mathrm{ND}$ & 0.10 & 0.15 & 0.11 & 0.70 & 17.00 & 7.98 & 100.00 \\
\hline & $\mathrm{A} 2 \mathrm{NY100}$ & 71.40 & 15.00 & 2.20 & 2.00 & 0.50 & 0.20 & $\mathrm{ND}$ & 0.10 & 0.50 & 0.51 & 0.1 & 7.36 & 0.13 & 100.00 \\
\hline $\mathrm{P} 3$ & $\mathrm{~A} 3 \mathrm{NY50}$ & 65.15 & 13.80 & 3.00 & 2.00 & 0.50 & 0.20 & 0.05 & 0.05 & 0.08 & 0.05 & 0.05 & 10.00 & 5.00 & 99.93 \\
\hline
\end{tabular}

\subsection{Mineralogy}

Fig. 2a, 2b and $2 \mathrm{c}$ present the diffractograms of alluvial materials from the Nyong valley. Analysis of the different diffraction lines reveals that the crystalline phase consists essentially of three minerals: quartz, kaolinite and maghemite.
The abundance of quartz is linked to two factors, including its higher resistance to weathering and geomorphological conditions (Ndigui et al 2008). The Nyong Valley being the lowest altitude unit, it is therefore very favorable to the reception of weathering products (Ndam,1997). 


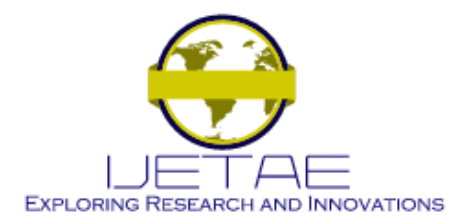

International Journal of Emerging Technology and Advanced Engineering

Website: www.ijetae.com (ISSN 2250-2459, ISO 9001:2008 Certified Journal, Volume 10, Issue 07, July 2020)
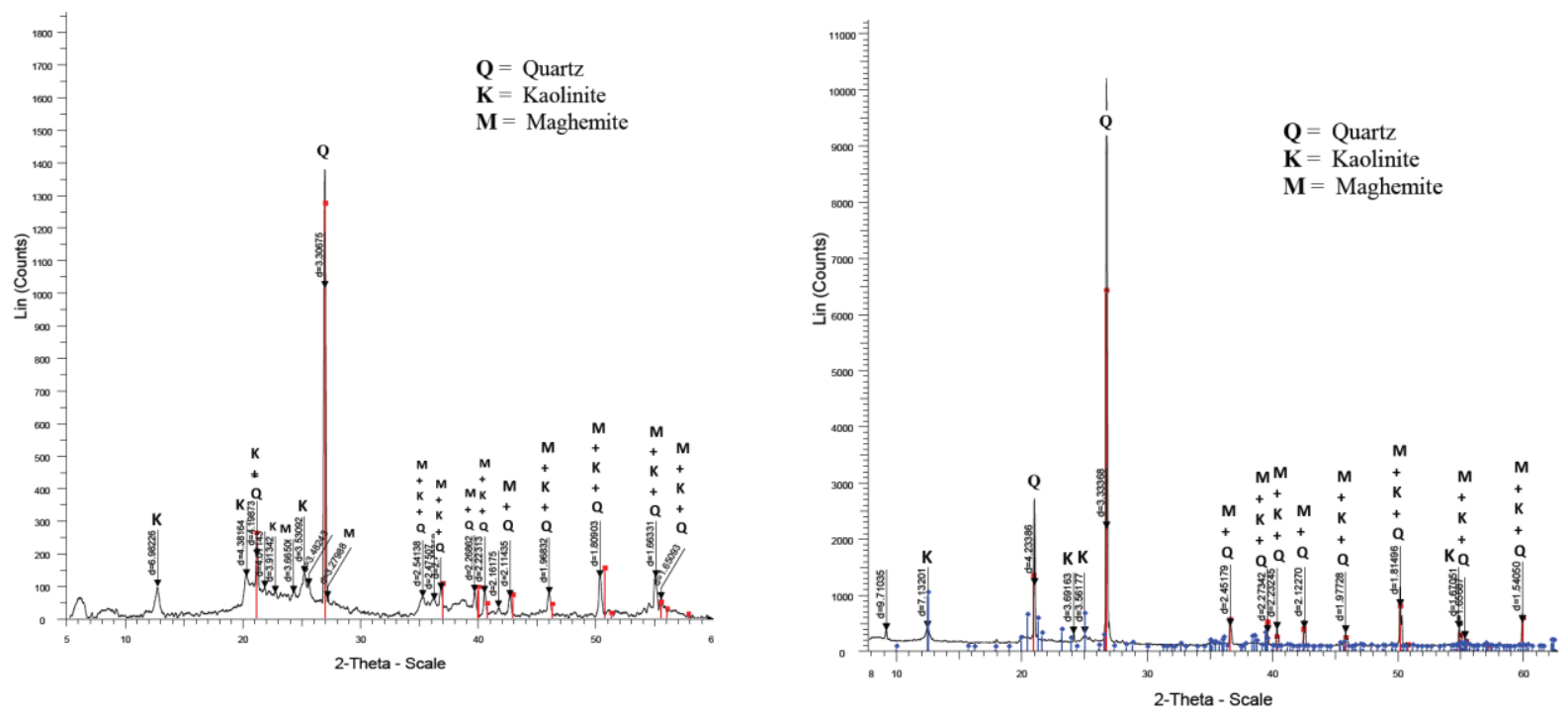

Fig. 2a. Diffactograms obtained from the X-ray diffraction analysis of alluvial materials from the Nyong valley at Akonolinga, in well P1
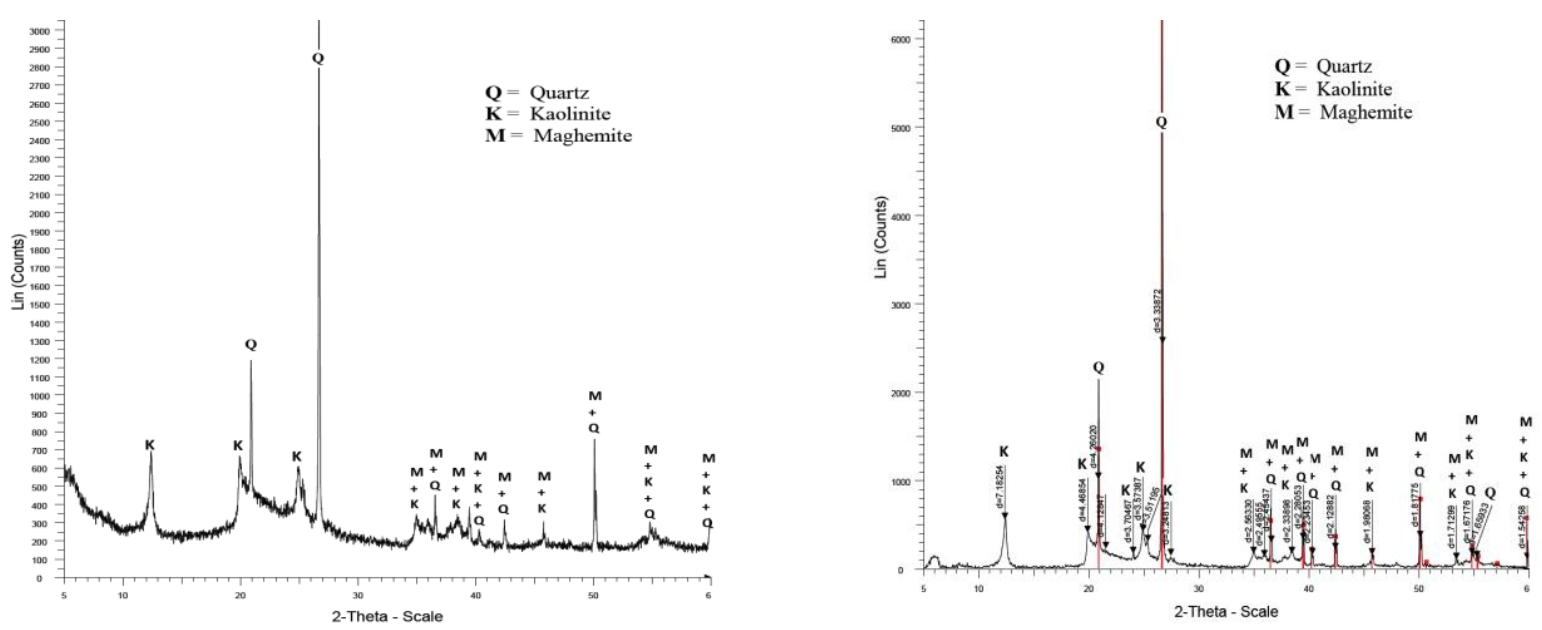

Fig. 2b. Diffactograms obtained from the X-ray diffraction analysis of alluvial materials from the Nyong valley at Akonolinga, in well P2
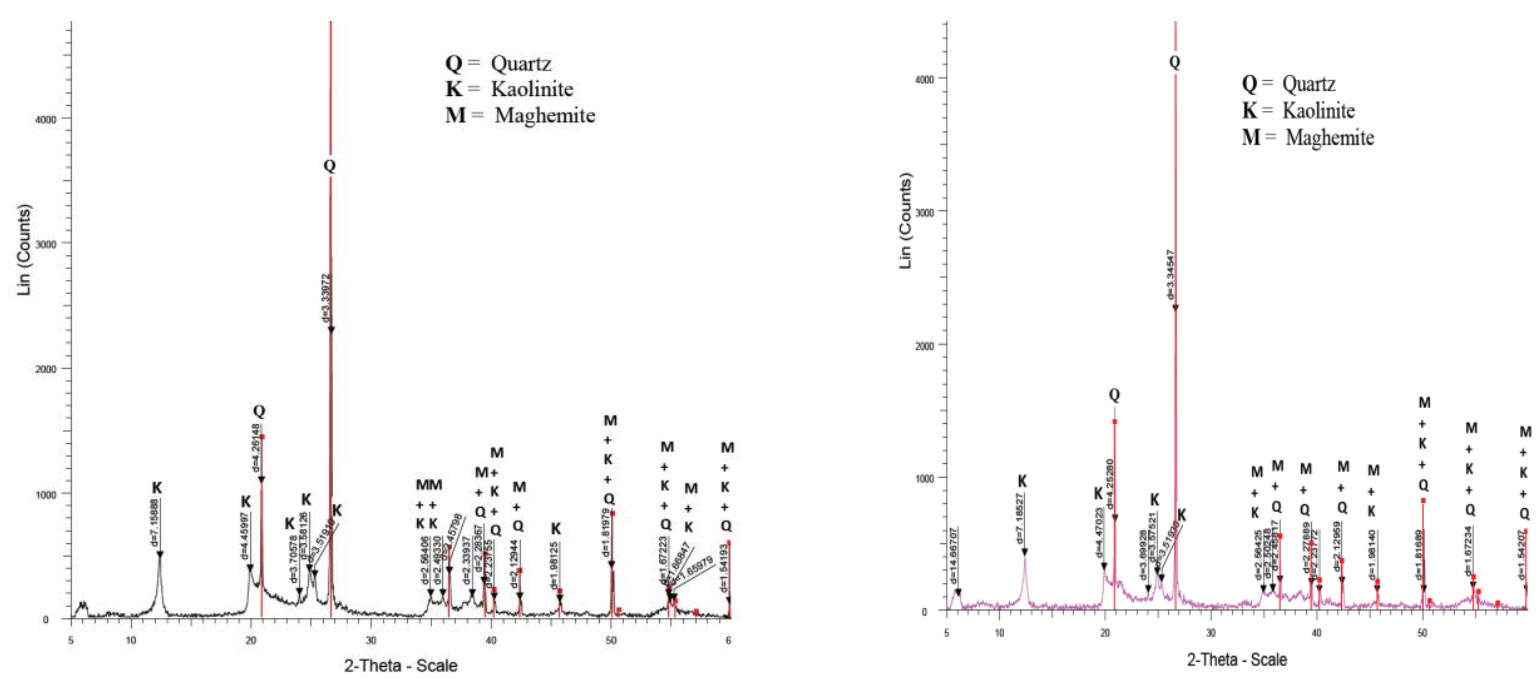

Fig.2c. Diffactograms obtained from the X-ray diffraction analysis of alluvial materials from the Nyong valley at Akonolinga, in well P3 


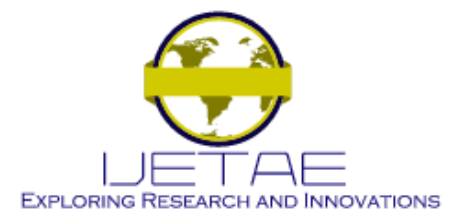

\section{International Journal of Emerging Technology and Advanced Engineering Website: www.ijetae.com (ISSN 2250-2459, ISO 9001:2008 Certified Journal, Volume 10, Issue 07, July 2020)}

\subsection{Fertility}

\subsubsection{Organic matter, Carbon and Nitrogen}

Organic matter is intruded into three particle size families (clay, silt and sand). Clays constitute the largest fraction $(55.30 \%)$ followed by silts $(30.55 \%)$ and at the end of the sand (14.14). The clay sheets allow the exchangeable bases to be fixed while the sand intervenes in the permeability of the soil (Kamgang Kabeyene, 1998). The fertility of the soil will depend on the one hand on the way in which the clays fix and release the exchangeable cations, and on the process of mineralization of organic matter (Marx et al., 1996). The sand makes the soil porous and thus allows the circulation of water. Organic matter plays an important role in soil fertility because it is the source of mineralproducing litter after it decomposes (Samba et al., 2015). Through the three opened wells in the study site, the evolution of organic matter indicates significant quantities at the surface (Table 2). The results obtained in the humiferous horizon show the following percentages: $\mathrm{A} 1 \mathrm{NY} 0=16.91 \% ; \mathrm{A} 2 \mathrm{NY0}=14.02 \%$ and $\mathrm{A} 3 \mathrm{NYO}=$ $15.62 \%$. This evolution is concomitant with that of all the other chemical elements entering into the composition of organic macromolecules, example of Carbon (C) and Nitrogen (N). The work of Euroconsult (1989) in Enyegue (2012) makes it possible to assess the fertility of materials as a function of the rate of organic matter and its various constituents. The availability of large quantities of organic matter may explain the origin of the coffee-black color of the waters of the Nyong River (Samba et al., 2015). It would be the dissolution in the water of the stream of the mixture resulting from the organic matter of surface of black color and clays of yellow or ocher color. The abundance of Suspended elements in the Nyong could also originate in the continuous supply of its bed by this organo-mineral deposit (Ndam, 1997). On the other hand, the $\mathrm{C} / \mathrm{N}$ ratio remains lower than the reference value $(\mathrm{C} / \mathrm{N}>25)$. This deficit could suggest a slow mineralization of organic matter. The range of the recommended value $\mathrm{C} / \mathrm{N}>25$ is obtained only in a single sample, A1NY80 of P1(Samba et al., 2015). In all the other samples $5<\mathrm{C} / \mathrm{N}<23$ reflecting slow mineralization. This situation can constitute a limitation for the nitrogen nutrition of plants.

\subsubsection{Assimilable phosphorus}

Phosphorus has shown two types of evolution, not only its rate is very important at the surface $(139.49 \mathrm{mg} /$ $\mathrm{kg}$ for A1NY0; $122.72 \mathrm{mg} / \mathrm{kg}$ for A2NY0 and $13.07 \mathrm{mg}$ / $\mathrm{kg}$ for A3NY0) at the expense of depth $(16.24 \mathrm{mg} / \mathrm{kg}$ for A1NY80; $3.82 \mathrm{mg} / \mathrm{kg}$ for A2NY80 and $1.07 \mathrm{mg} / \mathrm{kg}$ for A3NY80) (Table 2). But also, this rate decreases as one moves away from the Nyong bed.
This evolution is identified with that of organic matter and associated elements and seems to depend on several factors. According to Voundi Nkana (1998), the phosphate ions establish strong bonds with the clayhumic complex, at this time, the phosphorus is in the adsorbed form which is difficult to obtain. The fixation of phosphoric ions on this complex is all the stronger when the $\mathrm{pH}$ is acidic. This acidity makes the phosphorus less mobile and causes the precipitation of complexes such as iron phosphate and alumina phophate. On the surface, phosphorus is contained in organic matter and it is continuously released by decomposition of the latter. However, in depth organic matter becomes scarce and phosphorus is almost completely fixed by the clay fraction. The null value of phosphorus at a level of withdrawal would mean that the small bioavailable quantity is quickly fixed by the plant. In all cases, this behavior of assimilable phosphorus confirms the fact that ferralitic soils and the soil formations which depend on them are characterized by the low content of assimilable phosphorus whose rate decreases with depth (Meyim, 2000).

\subsubsection{Soil acidity: $\mathrm{pH}$}

The $\mathrm{pH}$ has a direct influence on the fertility of the soil; plant nutrition and biological activity. It affects the availability of nutrients, their toxicity and the activity of microorganisms (Meyim, 2000). When the $\mathrm{pH}$ is low, it induces toxicity and when it is high, the availability of certain nutrients such as iron and manganese decreases (Kamgang Kabeyene, 1998). When the $\mathrm{pH}$ is close to neutral all the elements of the soil can be assimilated (Anonymous, 2000). All the samples collected reflect an acidic soil with $4.55 \leq \mathrm{pH}$ water 55.15 . The $\mathrm{pHKCl}$ evolves in the same direction with $3.72 \leq \mathrm{pHKCl} \geq 4.78$ (Table 2). The potential acidity $\Delta \mathrm{pH}$ obtained is close to 1 , which means that the alluvial materials of Nyong are subject to acidification due to ions $(\mathrm{Al} 3+$ and $\mathrm{H}+$ ). Enyegue (2012) has shown that in all cases, acidity has a negative influence on the availability of elements. It causes the dissolution of elements such as aluminum and ferric iron with the consequences of increasing the aluminum toxicity and the retention of phosphorus by the formation of iron phosphates not available to the plant. This acidity also causes the unavailability of potassium $(\mathrm{K})$ and that of magnesium $(\mathrm{Mg})$ as well as the decrease in microbial activity, essential motor of the mineralization of organic matter. By favoring the formation of complexes, the acid $\mathrm{pH}$ strengthens the adhesion of cations to the clay-humic complex. The consequences are the decrease in base availability, the reduction in cation exchange capacity (CEC) and the fall in base saturation rate ( $\mathrm{S} / \mathrm{T})$. 


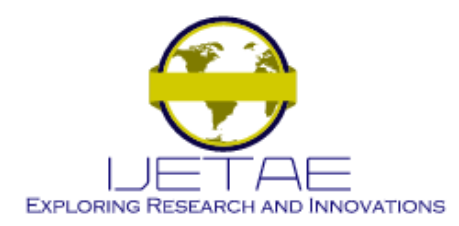

International Journal of Emerging Technology and Advanced Engineering Website: www.ijetae.com (ISSN 2250-2459, ISO 9001:2008 Certified Journal, Volume 10, Issue 07, July 2020)

Table 2

Evolution of fertility element across the valley

\begin{tabular}{|l|l|l|l|l|l|l|l|l|l|}
\hline Wells & Samples & Org.Mat $(\%)$ & $\mathrm{C}(\%)$ & $\mathrm{N}(\%)$ & $\mathrm{C} / \mathrm{N}$ & $\mathrm{P}(\mathrm{mg} / \mathrm{kg})$ & $\mathrm{pH}$ water & $\mathrm{pH} \mathrm{KCl}$ & $\mathrm{Al}^{3+}+\mathrm{H}^{+}(\mathrm{Cmol} / \mathrm{kg})$ \\
\hline P1 & A1NY0 & 16.91 & 9.83 & 1.80 & 5.46 & 139.49 & 5.03 & 3.85 & 3.66 \\
\hline & A1NY20 & 14.95 & 8.69 & 1.28 & 6.79 & 28.41 & 5.15 & 4.48 & 1.58 \\
\hline & A1NY50 & 13.48 & 7.84 & 3.75 & 2.12 & 16.45 & 4.55 & 3.82 & 2.01 \\
\hline & A1NY80 & 7.24 & 4.21 & 0.09 & 46.78 & 16.24 & 4.72 & 3.89 & 1.30 \\
\hline P2 & AN2Y0 & 14.02 & 8.15 & 3.56 & 2.29 & 122.72 & 4.74 & 3.90 & 5.51 \\
\hline & A2NY20 & 6.69 & 3.89 & 0.23 & 16.91 & 16.52 & 4.77 & 3.82 & 5.19 \\
\hline & A2NY50 & 1.99 & 1.16 & 0.07 & 16.57 & 1.97 & 4.87 & 3.72 & 6.12 \\
\hline P3 & A3NY80 & 2.08 & 1.21 & 0.08 & 15.13 & 3.82 & 4.86 & 3.74 & 6.19 \\
\hline & A3NY20 & 3.47 & 9.08 & 0.80 & 11.35 & 13.07 & 4.58 & 3.85 & 5.49 \\
\hline & A3NY50 & 2.34 & 2.02 & 0.22 & 9.18 & 2.22 & 4.90 & 3.93 & 3.83 \\
\hline
\end{tabular}

ND: Not Detected; Org.Mat: Organic Matter

\subsubsection{Cation exchange capacity (CEC or T)}

The exchange capacity (Fig.3.) shows extreme values at the surface that can exceed 90 meq / $100 \mathrm{~g}$ while the reference range indicates that $10 \mathrm{meq} / 100 \mathrm{~g}<\mathrm{CEC}<15$ meq / 100g. This situation, which does not reflect a good cationic balance, certainly results from the deficit of cations in the soil. The extremely low values of the S / T saturation rate provide a better understanding of the behavior of CEC. The values of the saturation rate are insignificant ( $\mathrm{S} / \mathrm{T}<10 \%$ ) compared to the reference interval, $60 \%<\mathrm{S} / \mathrm{T}<80 \%$, (Nkouathio et al, 2007; Ntouala, 2015).

\subsubsection{Exchangeable bases}

The bases constitute a source of nourishment for plants and fulfill various specific functions during their development. Fig.4. shows the evolution of the concentration of these elements in the soil. Their content is generally insignificant compared to the reference values indicated by Marx et al. (1996); Nkouathio et al. (2007).
The authors recommend the values of $\mathrm{Mg}^{2}+$ varying between $1.5 \mathrm{meq} / 100 \mathrm{~g}$ and $3 \mathrm{meq} / 100 \mathrm{~g} ; \mathrm{K}^{+}$between $0.4 \mathrm{meq} / 100 \mathrm{~g}$ and $0.8 \mathrm{meq} / 100 \mathrm{~g}$ and $\mathrm{Ca}^{2+}$ between 3.5 meq / $100 \mathrm{~g}$ and $7 \mathrm{meq} / 100 \mathrm{~g}$. In addition, the availability of these nutrients (calcium, magnesium, sodium, potassium) is closely linked to the $\mathrm{pH}$ of the soil. When the soil is acidic, these elements are not bioavailable because they are strongly retained by the clay-humic complex. Alluvial deposits in the Nyong valley face this problem because of an acidic $\mathrm{pH} \quad(\mathrm{pH} \approx 5)$. The consequence is the formation of complexes and the induction of aluminum toxicity. Because, when the $\mathrm{pH}$ drops below 5.5 the contents of exchangeable $\mathrm{Al}$ increase exponentially and $\mathrm{Al}^{3}+$ can become the most abundant cation of the exchange complex (Voundi Nkana, 1998). Although these complexes contribute to the development of a good soil structure, they participate at the same time in the cohesion between the aggregates forcing the plant to exert more efforts to have water useful for its development. Chemical analyzes reveal that the different values obtained from the sum of the exchangeable bases are low compared to the reference values which must oscillate between $10 \mathrm{meq} / 100 \mathrm{~g}$ and $15 \mathrm{meq} / 100 \mathrm{~g}$ (Landon, 1984). 


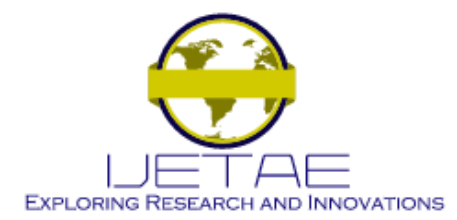

International Journal of Emerging Technology and Advanced Engineering

Website: www.ijetae.com (ISSN 2250-2459, ISO 9001:2008 Certified Journal, Volume 10, Issue 07, July 2020)

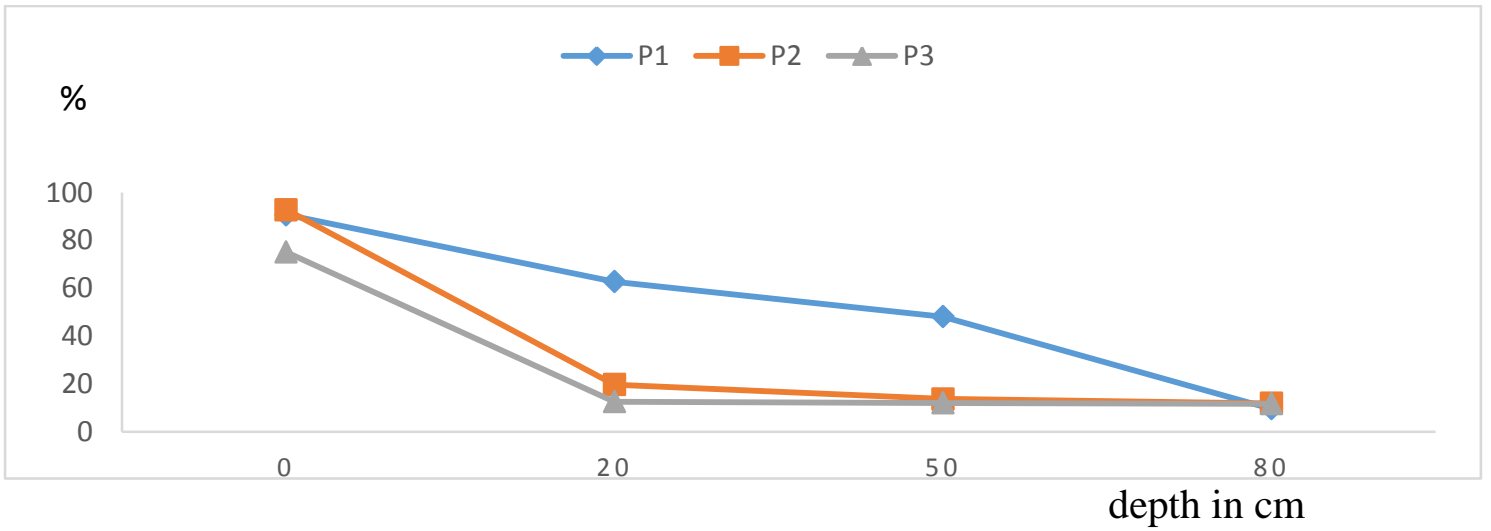

Fig. 3. Evolution of CEC in different wells

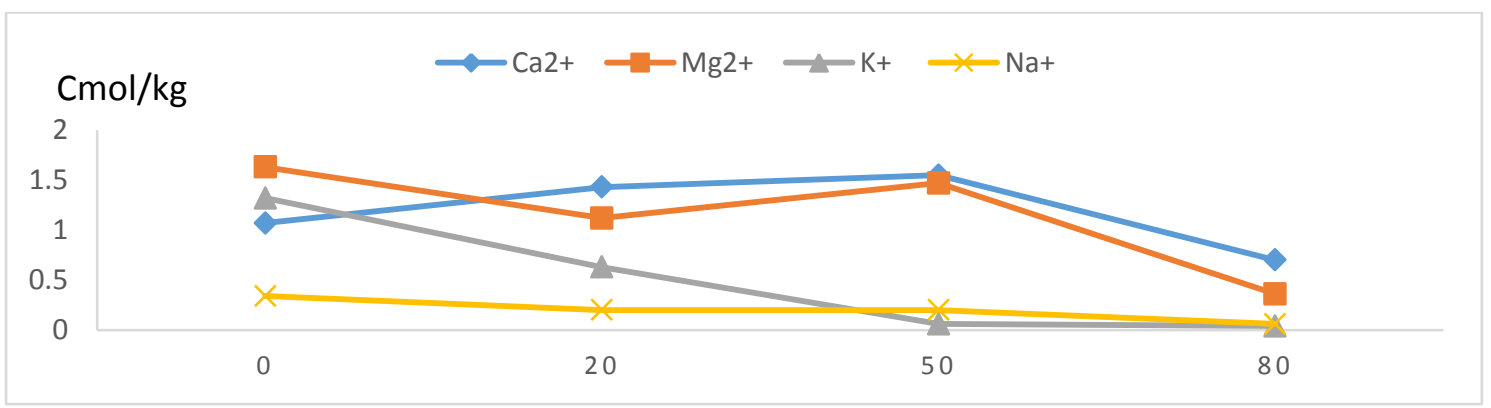

P1

depth in $\mathrm{cm}$

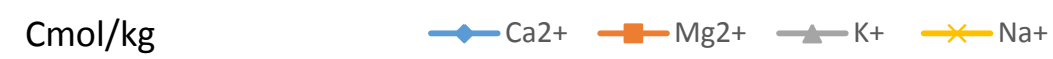

1.5

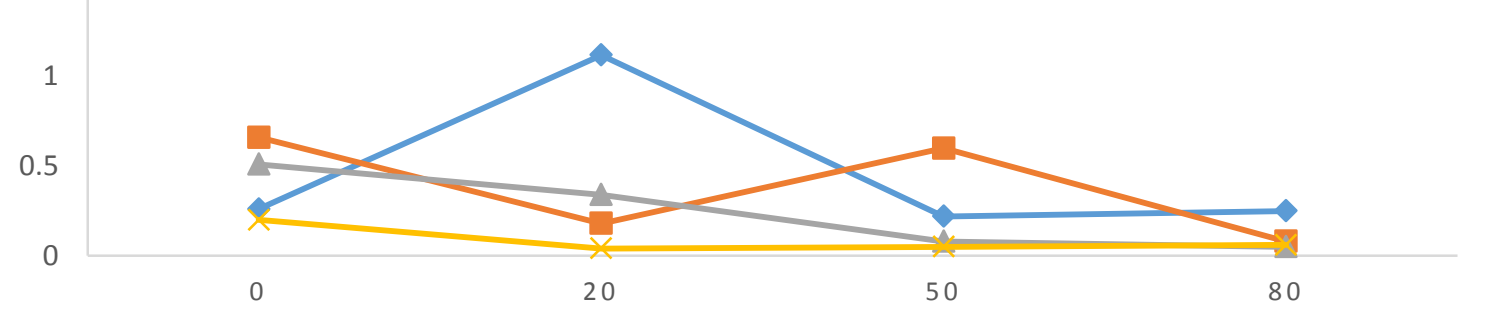

$\mathrm{P} 2$

depth in $\mathrm{cm}$

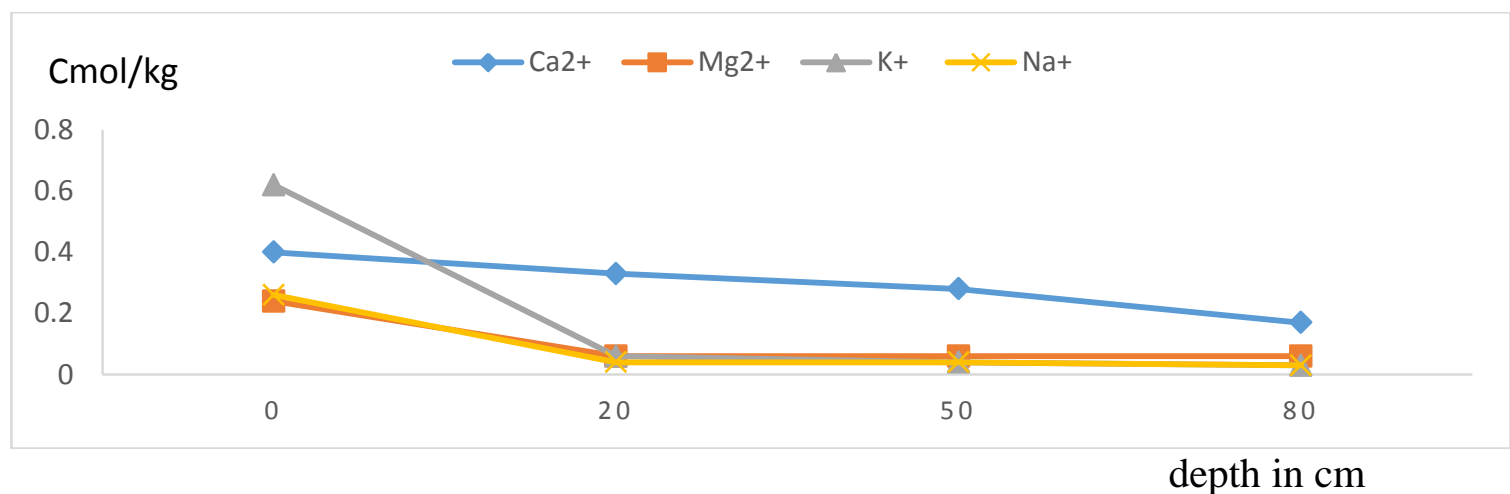

Fig.4. Evolution of the content of exchangeable cations in the various wells P1, P2 and P3 


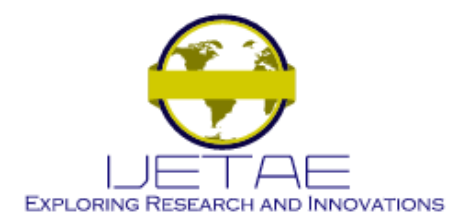

International Journal of Emerging Technology and Advanced Engineering

Website: www.ijetae.com (ISSN 2250-2459, ISO 9001:2008 Certified Journal, Volume 10, Issue 07, July 2020)

\subsubsection{Ionic balances}

\subsubsection{Balance $\mathrm{Ca} / \mathrm{Mg}$}

The $\mathrm{Ca} / \mathrm{Mg}$ binary balance diagram shows a concentration of the samples in an area of shared ion balance lines. This illustrates a generalized deficit in calcium and magnesium. However, this situation does not compromise the cationic equilibrium despite the location of the samples within the basal equilibrium zone. However, the A1NY20 and A1NY50 samples taken in P1 are the most representative. In order to elucidate this balance, reference must be made to the work of Lopes (1978) cited by Boyer (1982).
The author indicates that a good $\mathrm{Ca} / \mathrm{Mg}$ balance is in the ideal range $0.1<\mathrm{Ca} / \mathrm{Mg}>7.6$ which allows good absorption of magnesium by plants and average soil stability. Table 3 shows that the values of the $\mathrm{Ca} / \mathrm{Mg}$ ratios of all the samples are included in this reference interval. This further confirms the $\mathrm{Ca} / \mathrm{Mg}$ cation balance, although the content of these ions is insufficient in the alluvial materials of the Nyong valley. Establishing this cationic $\mathrm{Ca} / \mathrm{Mg}$ balance does not have a long-term fertilizing effect because of the very limited stock of these ions in the soil.

Table 3

Evolution of the $\mathrm{Ca}$ / $\mathrm{Mg}$ ratio across the materials of the Nyong valley

\begin{tabular}{|l|l|l|l|l|}
\hline Wells & Samples & $\mathrm{Ca}(\mathrm{Cmol} / \mathrm{kg})$ & $\mathrm{Mg}(\mathrm{Cmol} / \mathrm{kg})$ & $\mathrm{Ca} / \mathrm{Mg}$ \\
\hline P1 & A1NY0 & 1.07 & 1.63 & 0.60 \\
\hline & A1NY20 & 1.43 & 1.12 & 1.30 \\
\hline & A1NY50 & 1.55 & 1.47 & 1.05 \\
\hline & A1NY80 & 0.70 & 0.36 & 1.90 \\
\hline P2 & AN2Y0 & 0.26 & 0.66 & 0.30 \\
\hline & A2NY20 & 1.12 & 0.18 & 6.20 \\
\hline & A2NY50 & 0.22 & 0.60 & 0.30 \\
\hline & A2NY80 & 0.25 & 0.08 & 3.10 \\
\hline P3 & A3NY0 & 0.40 & 0.24 & 1.60 \\
\hline & A3NY20 & 0.33 & 0.06 & 5.50 \\
\hline & A3NY50 & 0.28 & 0.17 & 1.60 \\
\hline & A3NY80 & 0.06 & 0.06 & 1.00 \\
\hline
\end{tabular}

\subsubsection{Balance $\mathrm{Mg} / \mathrm{K}$}

$\mathrm{The} \mathrm{Mg} / \mathrm{K}$ ratio shows a deficiency of the samples in these two cations. This deficit does not have an impact on the $\mathrm{Mg} / \mathrm{K}$ equilibrium because most of the samples belong to the limit equilibrium zone. As in the $\mathrm{Ca} / \mathrm{Mg}$ binary diagram, the samples taken in P1 (A1NY0; A1NY20) have a preferential location in this equilibrium zone. To these samples is added that taken from the surface (A2NY0) in the second well (P2). This balance suggests that patassium can be absorbed in the presence of magnesium and freezes within the limits of their availability.
This suggestion is in agreement with the work of Boyer (1982) which indicates that a $\mathrm{Mg} / \mathrm{K}$ ratio <4 is favorable for good absorption of potassium in the presence of magnesium. The values of the $\mathrm{Mg} / \mathrm{K}$ ratio are ideal $(\mathrm{Mg} / \mathrm{K}<4)$ for all the samples taken at the surface to the detriment of a few depths (A1NY50, A1NY80, A2NY50, A3NY50). The establishment of cationic equilibria and the identification of the reference values of the $\mathrm{Mg} / \mathrm{K}$ ratio are necessary for potential fertility (Table 4). This is made hypothetical in the present case by the very insufficient rate of cations in the soil which constitutes a factor limiting current fertility. 


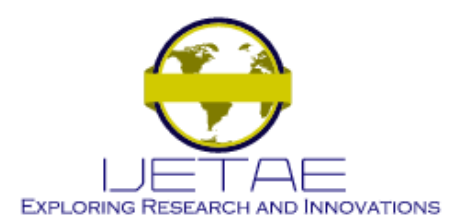

International Journal of Emerging Technology and Advanced Engineering Website: www.ijetae.com (ISSN 2250-2459, ISO 9001:2008 Certified Journal, Volume 10, Issue 07, July 2020)

Table 4

Evolution of the $\mathrm{Mg}$ / $\mathrm{K}$ ratio across the materials of the Nyong valley

\begin{tabular}{|l|l|l|l|l|}
\hline Wells & Samples & $\mathrm{K}(\mathrm{Cmol} / \mathrm{kg})$ & $\mathrm{Mg}(\mathrm{Cmol} / \mathrm{kg})$ & $\mathrm{Mg} / \mathrm{K}$ \\
\hline P1 & A1NY0 & 1.32 & 1.63 & 1.12 \\
\hline & A1NY20 & 0.63 & 1.12 & 1.7 \\
\hline & A1NY50 & 0.06 & 1.47 & 24.5 \\
\hline & A1NY80 & 0.04 & 0.36 & 9.0 \\
\hline P2 & AN2Y0 & 0.51 & 0.66 & 1.24 \\
\hline & A2NY20 & 0.34 & 0.18 & 0.5 \\
\hline & A2NY50 & 0.08 & 0.60 & 7.5 \\
\hline & A2NY80 & 0.05 & 0.08 & 1.6 \\
\hline P3 & A3NY0 & 0.62 & 0.24 & 0.3 \\
\hline & A3NY20 & 0.06 & 0.06 & 1.0 \\
\hline & A3NY50 & 0.04 & 0.17 & 4.25 \\
\hline & A3NY80 & 0.03 & 0.06 & 2.0 \\
\hline
\end{tabular}

\subsubsection{Balance $\mathrm{Ca} / \mathrm{Mg} / \mathrm{K}$}

$\mathrm{The} \mathrm{Ca} / \mathrm{Mg} / \mathrm{K}$ balance is studied using a triangular diagram delimiting within it an area of optimal equilibrium. This study is completed by the calculation of the $\mathrm{Ca} / \mathrm{Mg} / \mathrm{K}$ ion balance reports with reference to the ideal balance 76/18/6 (Nkouathio et al 2007). The different illustrations are made after having weighted the values of the ionic concentrations. The triangular cation balance diagram shows a concentration of the samples away from the optimal equilibrium zone. This is a general imbalance in the $\mathrm{Ca} / \mathrm{Mg} / \mathrm{K}$ cation balance.
However, these samples are located in an area of magnesian prevalence. This suggests that the imbalance in the cation balance is due to an excess of magnesium. Using the results of the $\mathrm{Ca} / \mathrm{Mg} / \mathrm{K}$ ratio makes it possible to confirm this imbalance in the cationic balance and to identify the causes. We then realize that all the ratios deviate from the ideal balance 76/18/6 (Table 5). This situation is due to a deficit in $\mathrm{Ca} 2+$ and a subsequent surplus in $\mathrm{Mg} 2+$ and $\mathrm{K}+$; this further explains why magnesium and potassium absorption is favorable.

Table 5

Evolution of the $\mathrm{Ca} / \mathrm{Mg} / \mathrm{K}$ report across the materials of the Nyong valley

\begin{tabular}{|l|l|l|}
\hline Wells & Samples & Cationic report Ca/Mg/K \\
\hline P1 & A1NY0 & $26.60 / 40.54 / 32.80$ \\
\hline & A1NY20 & $44.96 / 35.20 / 19.80$ \\
\hline & A1NY50 & $50.32 / 47.72 / 1.94$ \\
\hline & A1NY80 & $63.63 / 32.72 / 3.60$ \\
\hline P2 & AN2Y0 & $18.18 / 46.15 / 35.66$ \\
\hline & A2NY20 & $68.29 / 10.97 / 20.73$ \\
\hline & A2NY50 & $24.44 / 66.66 / 8.80$ \\
\hline & A2NY80 & $60.90 / 19.5 / 12.19$ \\
\hline & A3NY0 & $31.74 / 19.04 / 49.20$ \\
\hline & A3NY20 & $73.33 / 13.33 / 13.33$ \\
\hline & A3NY50 & $57.1434 .69 / 8.16$ \\
\hline & A3NY80 & $40 / 40 / 20$ \\
\hline
\end{tabular}




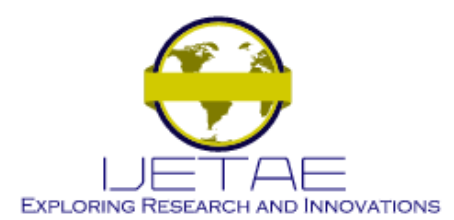

International Journal of Emerging Technology and Advanced Engineering

Website: www.ijetae.com (ISSN 2250-2459, ISO 9001:2008 Certified Journal, Volume 10, Issue 07, July 2020)

\subsection{Biofertilization}

Biofertilization involved the search for spores of mycorrhizal fungi which play an essential role in the fixation of phosphorus (Marx et al., 1996; Yemefack,2005). The results obtained (Table 6) are based on the morphological characters (size, color, shape). It appears from this table that three types of fungi have been trapped (T1, T2 and T3) corresponding to three genera (Glomus, Gigaspora and scutellospera).
Apart from the sample taken in P1 which contains only one type of fungus T1 (genus Glomus), the other two samples each contain two different types of fungus. The sample taken in P2 contains type T2 (genus Gigaspora) and type T3 (genus Scutellospera). As for the sample taken in P3, it contains the T2 type (genus Gigaspora) and the T1 type (genus Glomus).

Table 6

Morphological parameters of the mycorrhizal spores trapped in the samples

\begin{tabular}{|l|l|l|l|l|l|}
\hline Wells & Samples & Color & Size $(\emptyset)$ in $\mu \mathrm{m}$ & \multicolumn{1}{l|}{ Type } & Genus \\
\hline P1 & mixture & white & $125<\emptyset<250$ & T1 & Glomus \\
\hline P2 & mixture & white & $\emptyset>250$ & T2 & Gigaspora \\
\hline & & black & $\emptyset>250$ & T3 & Scutellospera \\
\hline P3 & mixture & white & $\emptyset>250$ & T2 & Gigaspora \\
\hline & & white & $125<\emptyset<250$ & T1 & Glomus \\
\hline
\end{tabular}

\section{$\emptyset$ :diameter of spore}

\subsection{Floristic Inventory}

Table 7 presents the floristic synthesis of the aquatic grasses of the alluvial terrace of Nyong in Akonolinga. From this table, it appears that the alluvial terrace is poor in terms of flora compared to the results obtained in savana in east region by Kamga Kabeyene (1998). On a defined area of $160000 \mathrm{~m}^{2}$, only ten families are listed and very unequally distributed. The Poaceae family is best suited to this surface; the other families are rare and the species appear either in the form of fragile recruits or in the form of isolated shrub species. The greater abundance of Poaceae on this surface has been accompanied by various adaptations. Not only do the stems cover large areas of the ground, gripping each time thanks to their adventitious roots pushed at their nodes, but also these stems become entangled between them to form a carpet on the ground which suffocates other individual's plants.
Taxonomic dynamics make it possible to distinguish two groups; permanent vegetation made of Poaceae with Digitaria Adamaonensis and Echinochloa throughout the year and vegetation made of regrowth limited to the dry season when the surface invaded by Poaceae is devastated by bush fires. The floristic synthesis made it possible to highlight the dominant floristic family (Poaceae) as well as the characteristic species (Digetaria Adamaonensis and Echinochloa) of the alluvial terrace of Nyong in Akonolinga and thus to envisage specific substitution. Given the homogeneity of the aquatic prairie, morphological characteristics, systematic position, life cycle and water requirements, the substitution of the Nyong aquatic prairie can be done by Zea mays (corn) or by Oryza Sp (rice). Rice cultivation seems indicated at the expense of the cultivation of corn thanks to the flexibility of the stem of the rice plant because the Nyong terrace is exposed to the effect of the wind (Théka Diouf, 1998; Gue 2001). 


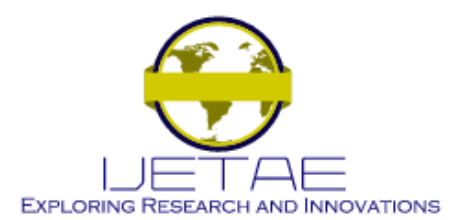

International Journal of Emerging Technology and Advanced Engineering Website: www.ijetae.com (ISSN 2250-2459, ISO 9001:2008 Certified Journal, Volume 10, Issue 07, July 2020)

Table 7

Floristic inventory on $16,000 \mathrm{~m}^{2}$ area of aquatic meadow in the Nyong valley

\begin{tabular}{|l|l|l|}
\hline Families & Species & Relative abundance \\
\hline Fabaceae & Tephrosia vogelu & - \\
\hline Cyperaceae & Bublostylis pusilla & - \\
\hline Melastomataceae & Dissotis brazzae & - \\
\hline & Bracharia mutica & + \\
\hline & Digitaria adamaonensis & ++ \\
\hline & Pennesetum ledermamau & ++ \\
\hline & Panicum maxima & ++ \\
\hline Poaceae & Echinochloa sp & ++ \\
\hline & Echinochloa cruspavonis & ++ \\
\hline & Pennesetum purpureum & ++ \\
\hline & Echinochlo apyramidalis & ++ \\
\hline Polygonaceae & Polygonum acuminatum & - \\
\hline Asteraceae & Ethulia conyzoides & - \\
\hline Solanaceae & Solanum sp & - \\
\hline Tiliaceae & Clapertonia ficifolia & - \\
\hline Dennstaedtiaceae & Pteridium aquilinum & - \\
\hline & & + \\
\hline & & + \\
\hline
\end{tabular}

\section{DisCUSSION OF RESUlts}

The fertility of the alluvium of the Nyong valley at Akonolinga is part of the same logic as the studies that have been done in this area on ferralitic soils (Dooremboss et Kassam, 1980; Medjo Akoo, 1982; Boyer, 1982; Landon, 1984; Posner 1988; Nyeck, 1989; Marx et al ,1996; Voundi Nkana, 1998; Dembele 2000; Meyim Dayombo, 2000; Yemefack, 2005). According to Landon (1984), the characteristics of these soils (acid soils, rich in silica, Iron and Kaolinite) as well as the associated formations are common. However, in Cameroon, the evaluation of fertility parameters in the Nyong valley and in Sa'a soils (Enyegue, 2012) shows a slight improvement compared to the fertility observed in the Yaoundé region under virgin forest or fallow (Voundi Nkana, 1998; Ntouala, 2015). The quantities of organic matter are greater in the Nyong valley than in Mbalmayo under fallow (Voundi Nkana, 1998) and under virgin forest in Sa'a (Enyegue, 2012). In all these soils, mineral elements such as nitrogen and phosphorus evolve in the same direction as organic matter. The $\mathrm{C} / \mathrm{N}$ ratios do not indicate good mineralization. The $\mathrm{pH}$ values are in the range of acidity. Landon (1984) considers that the acidification of the profiles of non-calcareous soils is due to the fact that the leached alkaline and alkaline earth ions are replaced on the absorbent complex by the $\mathrm{H}+$ and $\mathrm{Al} 3+$ ions. When the $\mathrm{pH}$ exceeds 5.5 aluminum does not exist in exchangeable form.
If it drops below this limit, the exchangeable aluminum increases exponentially and can become the most exchangeable cation of the absorbent complex, thus inducing aluminum toxicity (Evans and Kamparath, 1970). In general, the content of exchangeable bases is insufficient because of their dynamics dominated by leaching (Boyer, 1982). The cation exchange capacity (CEC) of these soils is low and shows the same trend as that of the content of exchangeable bases. The CEC is more important in the soils of Sa's followed by that of the alluviums of Nyong in Akonolinga and finally that of the soils of Mbalmayo. Because of the acidity of ferralitic soils which makes them less and less fertile, their development requires the prior evaluation of cultural aptitudes (Nyeck, 1989 and Enyegue, 2012). For homogeneous vegetation such as the aquatic prairie in the Nyong Valley, it is desirable to replace species. According to Voundi Nkana (1998), the chemical fertility of these soils can be improved by using waste from the wood industry. Nkouathio et al (2007) recommend the use of volcanic rocks such as basalt pyroclastites of the Tombel graben (Cameroon volcanic line) for the remineralization of ferralitic soils in tropical regions. In contrary to results obtained in Nyong valley in Cameroon, the studies conducted in India to assess the soil fertility in watershed in Northern Brattmaputa zone (Bipul Deka et al., 2017) or in semiarid tropics (Muniasmy et al., 2013) and in Toshka area of Egypt (Mamdouh et al., 2019) shown great quantity of micro nutriments $(\mathrm{Fe}, \mathrm{Cu}, \mathrm{Mn}$, Zinc); small quantity of organic Matter and large value of $\mathrm{pH}$ (from basic to acidic). 


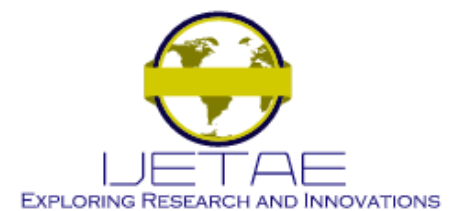

\section{International Journal of Emerging Technology and Advanced Engineering Website: www.ijetae.com (ISSN 2250-2459, ISO 9001:2008 Certified Journal, Volume 10, Issue 07, July 2020)}

The difference in results obtained can be explain by taking in account the environment in which samples come from, given that ferralitic soils are poor according to the fertility.

\section{CONCLUSION}

At the end of this study, we draw the following conclusions:

- The valleys are characterized by the abundance of organic matter that accumulates;

- The $\mathrm{pH}$ of valleys is acidic like ferralitic soils from that they derive;

- The content of cation in the valley is low;

- The cation exchange capacity remains limited;

- The large amount of organic matter is an advantage to quick improve the fertility in valley areas;

- Silica is the abundant major chemical element while quartz and kaolinite are the best identified minerals;

- It is possible to replace the aquatic grasses in the valley with the cultivation of aquatic rice.

\section{REFERENCES}

[1] A. Aboeme. Influence of macrophytes on the flow of suspended matter in the upstream watershed of Nyong, DESS - UNV de Ydé 173 P, 2007.

[2] D. Bipul Maruthi Sankar, G. Marami Dutta, T. Barnah., Puspanjali, V. Visha Kumari, P. Mishra. Assessment of fertility potential for the soils of northern brattmaputa zone using principal component analysis, Ind. J. Soil Cons.45(1):1-11,2017.

[3] E. Bineli. 2009. Impact of climatic variability on the water resources of the Nyong basin, Master FAC. Sc. UYI., 82 P, 2009.

[4] Y. Boulevert. Soil map (fertility) of Ouham, R.C. A, at 1/200000 and explanatory note $\mathrm{n}^{\circ} 58$, ORSTOM. Paris, 1975.

[5] J. Boyer. Ferralitic soils: Fertility factor and soil use, Init. Doc. tech. ORSTOM, Paris, 52,384P,1982.

[6] Y. Dembele. Irrigated rice growing, Inter-State School of Engineers Rural Equipment (ElER). Ouagadougou. 53 P, 2000.

[7] J. Doorembos and A. Kassam. Response of water yields, Irrigation and drainage bulletin n 033. FAO, Rome (Italy). 221P,1980.

[8] E. Evans and J. Kamparath. Lime response and related to percent aluminum saturation, solution $\mathrm{Al}$ and organic matter content, Soil Sci. Soc. Bitter. Proc., 34, 893-896, 1970.

[9] A. Enyegue. Fertility and cultural aptitudes of the soils of SA'A developed on granitic mica schists, DIPES II. ENS: UYI. 75P, 2012.

[10] E. Gue. Influence of the water regime on mineral nutrition and yield components of irrigated rice in the KOU valley west of BURKINA FASO, I.N.R.A.Dipl. Ing. from Dev. Rur.106 P ,2001.

[11] J. Guignard. Abbreviated Botany Ed. MASSON, Paris. Milan Barcelona, 261 P, 1994.

[12] V. Kamgang Beyala. Supergene evolution of rocks and phytogeographic incidences: case of the savannah forest contact of South East Cameroon, Thesis, Doc. State Fac. Sc. Univ Ydé I 208 P, 1998.

[13] J. Landon. Booker tropical manual: a handbook for soil survey and agricultural land evaluation in tropics and subtropics, Booker agriculture international limited, London, pp.106-156, 1984.
[14] E. Marx, Hart, J. Stevens and R. Soil tests interpretation Guide, US Department of Agriculture, Oregon State University, 8 P,1996

[15] J. Medjo Ako'o. Evolution of the properties and cultural suitability of soils on micaceous quartzite from the sa'a region under semi-permanent tomato cultivation, DEA. FAC. Sc. UYI, 91P, 2001.

[16] Memento of the agronomist. Production of the Min. Of the coop. Fran. and from Dev,1635P, 2000.

[17] S. Meyim Dayombo. Effect of various fallows on the evolution of the fertility of a ferralitic soil near Yaoundé (Cameroon), Application to land assessment for the main crops grown in the region: Peanuts, Plantains, Corn, Cassava. Master. FAC. Sc. UYI, 60P, 2000.

[18] A. Mamdouh, A. Mamoud, Mohamed, A. Galal, Elgharably. Evaluation of soil fertility status in Thoshka, Egypt, Journal of Agricultural Sciences (15) (1): 1-06, 2019. DOI: 10.5829/ idosi wjas 2019.01.06

[19] Muniasmy Probhavathi., L. Patril, A.Raizada. Assessment of soil fertility status for sustainable crop production in a water shed of semiarid tropics in southern India, Ind. J. Soil Cons. 41(2): 151157, 2013.

[20] J. Ndam. Hydrogeochemical assessments under tropical forest in the Nyong and Sanaga hydrographic networks in South Cameroon. Th. Doc. Univ. Pierre and Marie Curie, Paris Vi. 214 $\mathrm{P}, 1997$.

[21] P.-D. Ndjigui, P. Bilong, D. Bitom, A. Dia. Mobilization and redistribution of major and trace element on two weathering profiles developed on serpentinites in the Lomié ultramafic complex, South-East Cameroon. J. Afr. Earth Sci.50, pp. 305-328, 2008.

[22] J. Nkouathio, P.Wandji, J.Bardintzeff, P.Temtio, D .Kagou., F. Tchoua. Use of volcanic rocks for the remineralization of ferralitic soils in tropical regions. Case of the basalt pyroclastites of the Tombel graben (volcanic line of Cameroon), Bull. Soc. Vaud. SC.Nat.91.1: 1-14, 2007

[23] F. Ntouala. Supergene alteration of the chloritoschists of Ayos (Center Cameroon), Th. Doct. / Ph. D, Fac. Sci. Univ. Yaoundé I, 269P,2015.

[24] B. Nyeck. Organization and cultural suitability of Zoétélé soils in the humid forest region of South Cameroon: Examples of two toposequences on granite, Th. Doc. 3rd cycle Univ. Ydé 324P, 1989.

[25] J. Posner, Contribution to agricultural knowledge of the lower Casamance, Bibliographic synthesis. MSU. International development paper.51P, 1988.

[26] P. Samba, E Chi, V. Kamgang Kabeyene. An explanation of the black color of river Nyong water and associated alluviums (Cameroon), International journal of Geoscience, 6, 388-392. 2015. http://dx.doiorg/10.4236/ii.2015.64030.

[27] Theka Diouf. Agrophysiology program, ISRA.42P,1988.

[28] D. Tremblay and V.Robitaille. Soil mechanics, theory and practice, ED. Modulo. Quebec-Canada. 652P, 1997.

[29] J. Voundi Nkana. Use of wood industry wastes to improve the chemical fertility of tropical acid soils, Th. Doct. 3rd cycle, IRAD. 202P, 1998

[30] M. Yéméfack. Spatio-temporal modeling of soil and land use dynamics within agricultural landscape mosaic systems of southern Cameroon, PhD thesis, ITC, Netherlands, 194 P, 2005.

* Corresponding author, Email: sambafilipe@yahoo.fr ; Phone. +237677466034. 